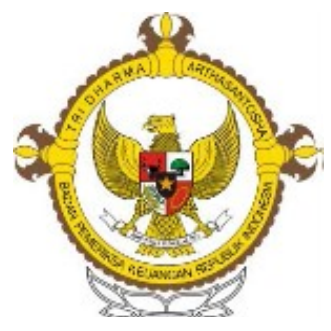

JURNAL

TATA KELOLA \& AKUNTABILITAS KEUANGAN NEGARA

Volume 5, Number 1, Jan-Jun 2019, 1-20

e-ISSN 2549-452X

p-ISSN 2460-3937

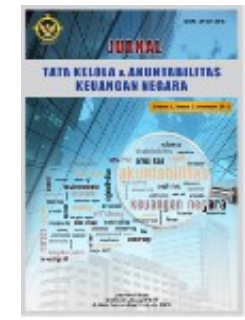

\title{
BUDGET TURBULENCE AND BUDGET DEVIATION: DO LOCAL GOVERNMENT HAVE THE ABILITY TO REDUCE THEM?
}

\author{
Eva Herianti \\ Universitas Muhammadiyah Jakarta \\ Evaherianti@gmail.com
}

\section{ABSTRACT}

The purpose of this study is to examine and analyse the effect of local governments' ability on the relationship between budget turbulence and budget deviation. The study sample uses the regional budget (APBD) report and realization of a number of districts/cities throughout Indonesia encompassing the 2014-2017 period, while the analysis covers the period from 2015-2017. This study uses the least square approach with EViews analysis tool version ten to test the hypothesis. Result of the study shows that budget turbulence has a positive and significant effect on budget deviation. The result also shows that the capacity of local governments can reduce the influence of budget turbulence on the budget deviation. Sensitivity tests using proxies of local governments not sampled by the main test also show consistent results. Finally, sensitivity test by area category proves that for the three categories, mainly western, central, and eastern Indonesia, the results are consistent with the main test results. The contribution of this study to the policies of the local governments is aimed to enhance efficiency of spending and increase productive spending to support the priority of government programs and encourage efficient, innovative and sustainable financing while maintaining the investment climate. Through several of these alternatives, the local government can overcome the conditions of resource instability that can threaten the effectiveness of the implementation of various programs.

\section{KEYWORDS:}

Budget turbulence; local government ability; budget deviation 


\section{INTRODUCTION}

The main issue often found in the process of budget preparation and application is budget deviation. Budget deviation is a condition that indicates a failure to control such budget that can potentially cause budget surplus (under-spending) or a deficit (overspending). In public sector organizations, budget deviation is a major issue in planning, control, and accountability in budget management. This happens because budget is one indicator used to measure performance of public sector organizations. Variance between budget planning and realization within an organization, whether favorable or unfavorable, i.e. surplus or deficit, proves that the budgeting process, from budget planning to control, is not running efficiently or effectively. One evidence of budget deviation in a public sector organization, particularly in a local government, is demonstrated by the municipal of Bekasi. The Bekasi municipal government experienced a deficits of Rp9oo billion in 2018 (AlFajri, 2018). The high deficit is due to the government spending being too large, without a corresponding guaranteed revenue. This condition indicates that the municipal government is less than effective in carrying out its financial planning and budgeting.

Surplus or deficit indicates that the budgeting process has not been carried out efficiently or effectively. Spending surplus does not mean that a government has carried out proper planning, control, and management of budget accountability. Rather, surplus demonstrates the lack of ability and discipline on the part of the government in preparing and realizing its budget (Johansson \& Siverbo, 2014). Furthermore Wirasedana, Sisdyani and Setiawan (2018) states that the ideal budget realization is the realization of a balanced budget, where the local government as far as possible avoids surplus and, more importantly, deficit. Table 1 presents surpluses and deficits in the realization of the local government budgets in Indonesia over the period of 2015-2017.

Table 1. Surpluses and Deficits Actual Budget

\begin{tabular}{cccc}
\hline Years & Surplus & Deficit & Balance \\
\hline 2015 & 316 & 225 & 1 \\
\hline 2016 & 224 & 318 & 0 \\
\hline 2017 & 316 & 226 & 0 \\
\hline
\end{tabular}

Source: Directorate General of Fiscal Balance

Processed by Researcher

Table 1 shows that during 2015-2017, local governments experienced multiple occasions of surplus and deficit. Balanced budget realization was only found in 2015. The data shows that local governments are still experiencing difficulties in effecting budget planning, control, and accountability in an effective and efficient manner. Halim and Kusufi (2014) state that when there is surplus, priority should be given to its application to cover principal debt, regional capital investment, lending to the central government/ other regions and/or funding for increased social security spending. Meanwhile, if there is deficit, financing to cover the deficit can be derived from the remaining balance of the previous year's budget (SILPA), disbursement of reserve funds, sale of separated regional assets, loan, and settlement of receivables.

Anessi-Pessina, Barbera, Rota, Sicilia, and Steccolini (2012) states that budgeting research in public sector organizations in the accounting and public administration literature that focuses on budget control-related outcomes is still rarely done by researchers. Furthermore, Anessi-Pessina et al. (2012) states that budgeting research in public sector organizations tends to be associated with changes in accounting standards and their implementation. Meanwhile, Wildavsky (1975), Jonsson (1982), Boland and Pondy (1986), Covaleski and Dirshmit (1988) fo- 
cused more on the decision-making process in budgeting. Therefore, recent research has begun to focus on budget control-related outcomes, such as Johansson and Siverbo's (2014) research, and Wirasedana et al. (2018). This study is a modification of the study of Johansson and Siverbo (2014), and Wirasedana et al. (2018) with a focus on research only on budget turbulence and budget deviation. Furthermore, the researcher introduces modifications through the use of moderating variables, such as the ability of local governments to deal with budget turbulence that can affect the occurrence of budget deviations. Thus, the focus of this study is on the skills of local governments in planning, controlling and being accountable for budget management efficiently and effectively in the face of budget turbulence as a result of economic upheavals and fiscal pressures in public sector organizations, thereby reducing the occurrence of budget deviations.

Local governments in the budget formulation process up to the budget realization stage need an appropriate and accurate strategy in determining the availability of resources or regional potentials that will be used in the realization of regional government programs. The availability of these resources will be used to support various local government programs through the revenue budget sourced from regional revenues, central government policies, local government policies, also micro and macro economic conditions.

Wirasedana et al. (2018) state that public sector organizations that face significant budget turbulence would likely encounter a more pronounced lack of synchronicity between the goals set by the central managers and those established by department managers. Furthermore, in situations where low or no budget turbulence is present, the budgeting process of a public sector organization is likely incrementalism-based. Low budget turbulence indicates that local governments only marginally departs from the previous year's budget (Boyne \& Meier, 2009). As a result, the process of planning, controlling, and accountability in managing the budget does not work efficiently and effectively, resulting in budget deviations.

To reduce the effect of budget turbulence on budget deviations, it requires the skills of local governments to manage budgets efficiently and effectively. The capability of local government is the ability of local governments to implement public policies through the management of their own resources to a minimum to produce maximum service quality in order to improve the welfare of the community. World Economic Forum (2015) states that government efficiency is associated with a reduction in regulatory burdens, increased transparency of regulations, and reduction in wasteful costs. Lee and Whitford (2009) also Portes and Haller (2010) state that the efficiency of local government will improve performance, so that the quality of community welfare services can be improved. The skills of local governments show the character of government officials in implementing public policies. Capable regional governments will be able to make public policy decisions to achieve levels of efficiency and effectiveness in managing government resources, have accurate estimation capabilities, have experience and understanding of the domain of public policy, have expertise in carrying out their duties, and can use strategies that are right on target. So that the regional government can manage and overcome the instability of the availability of resources, thereby minimizing the occurrence of budget deviations.

Based on the description of the background that the researcher has explained earlier, the formulation of the research problem is whether the local government has the ability to reduce the effect of budget turbulence on 
welfare. Based on the description, the hypothesis proposed is as follows.

H2 : The higher the local government's ability, the lower the influence of budget turbulence on budget deviations. Conversely, the lower the local government's ability, the higher the influence of the budgetary turbulence on the budget deviation.

The research model can be visualized as follows.

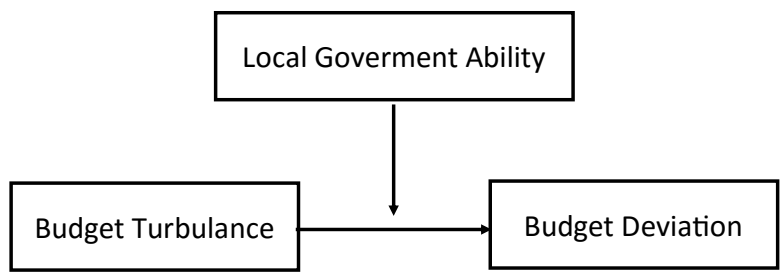

Figure 1. Research Model

\section{RESEARCH METHOD}

This study uses budget report data and realization of regional income and expenditure budgets of a number of districts/cities throughout Indonesia for the 2014-2017 period. This data source is obtained through the website of the Directorate General of Fiscal Balance. The study sample comprises of district/city governments throughout Indonesia. Meanwhile, the analysis covers the years 20152017. The sample selection covers the last three-year period in order to represent the current phenomenon, and 2014 is used as the base year in calculating research variables involving the previous period. This study uses budget turbulence, local government ability, and budget deviation, as variables. Table 2 presents the operational definition of the three research variables.

This study uses the least square approach to test the research hypothesis. This approach requires researchers to test classical assumptions, namely normality, multicollinearity, heteroscedasticity, and autocorrelation. This study does not use the normality test because the number of sample observations have fulfilled the criteria for the central limit theorem (Gujarati \& Porter, 2009). Meanwhile, this study uses a multicollinearity test to detect correlations between independent variables in the research model through tolerance values and VIF. The rule of thumb of TOL values $>0.1$ and VIF $<10$ indicates that there is no correlation between independent variables in the research model. The heteroscedasticities test uses white's heteroscedasticity-consistent variance and standard error to

Table 2. Operational Variable Definition

\begin{tabular}{|c|c|c|}
\hline Definition & Measurement & Scale \\
\hline $\begin{array}{l}\text { Budget Turbulence } \\
\text { Instability of resources to develop a budget } \\
\text { that can threaten the effectiveness of the } \\
\text { implementation of programs and activities to } \\
\text { improve public welfare. }\end{array}$ & $\begin{array}{c}\text { Budget Turbulence }= \\
\text { (Budget Revenue }-{\left.\text { Actual } \text { Cost }_{\mathrm{t}-1}\right) / \text { Actual Cost }_{\mathrm{t}-1}} \\
\text { (Adapted from Johansson \& Siverbo, 2014; and } \\
\text { modified by Wirasedana et al., 2018) }\end{array}$ & Ratio \\
\hline $\begin{array}{l}\text { Local Government Ability } \\
\text { The government's ability to manage owned } \\
\text { resources to produce maximum service in } \\
\text { order to improve people's welfare. }\end{array}$ & $\begin{array}{c}\text { Efficiency Ratio }= \\
\text { Actual Cost/Budget Cost } \\
\text { Effectiveness Ratio = } \\
\text { Actual Revenue/Budget Revenue } \\
\text { (Adapted from Hamid, 2018) }\end{array}$ & Ratio \\
\hline $\begin{array}{l}\text { Budget Deviation } \\
\text { A condition demonstrating the government's } \\
\text { failure to control budget that can potentially } \\
\text { cause surplus (under-spending) or a budget } \\
\text { deficit (over-spending). }\end{array}$ & $\begin{array}{c}\text { Budget Deviation = } \\
\text { (Budget Cost - Actual Cost)/Actual Cost } \\
\text { (Adapted from Johansson \& Siverbo, 2014; and } \\
\text { modified by Wirasedana et al., 2018) }\end{array}$ & Ratio \\
\hline
\end{tabular}

Source: Johansson \& Siverbo (2014); Hamid (2018); Wirasedena et al. (2018) 
correct the parameter values obtained by the least square method and its output can be used as the final result of hypothesis testing because the heteroscedasticity problem has been corrected (Ghozali \& Ratmono, 2017). Finally, the autocorrelation test uses the Durbin-Watson (DW) value with decisionmaking criteria as shown in table 3 .

Table 3. Decision of Autocorrelation Test

\begin{tabular}{cc}
\hline Decision & If \\
\hline Positive Autocorrelation & $<-2$ \\
\hline No Autocorrelation & -2 to +2 \\
\hline Negative Autocorrelation & $>+2$ \\
\hline
\end{tabular}

Source: Santoso (2010)

\section{RESULT AND DISCUSSION}

This study uses descriptive statistics to briefly explain the research variables. Table 4 shows descriptive statistics of research variables, namely, budget turbulence, local government ability of local as measured by efficiency ratio and effectiveness ratio, also budget deviation. Table 4 shows that the average budget deviation is 0.1155 . This value indicates that the average failure of the district/city governments in controlling their budget that can potentially cause surplus or deficit is $11.55 \%$. The average budget turbulence indicates that the local government is experiencing instability of resource used to

Table 4. Descriptive Statistics

\begin{tabular}{|c|c|c|c|}
\hline Variables & $\mathbf{N}$ & Mean & $\begin{array}{c}\text { Std. } \\
\text { Deviation }\end{array}$ \\
\hline BD & 1524 & 0.1155 & 0.1698 \\
\hline BT & 1524 & 0.3827 & 4.4340 \\
\hline ESR & 1524 & 91.2175 & 11.3345 \\
\hline EFR & 1524 & 95.5674 & 10.5126 \\
\hline \multicolumn{4}{|l|}{ Notes: } \\
\hline $\mathrm{BD}$ & \multicolumn{3}{|c|}{ = Budget Deviation } \\
\hline BT & \multicolumn{3}{|c|}{$=$ Budget Turbulence } \\
\hline ESR & \multicolumn{3}{|c|}{ = Efficiency Ratio } \\
\hline EFR & \multicolumn{3}{|c|}{ = Effectiveness Ratio } \\
\hline
\end{tabular}

develop a budget that can threaten the effectiveness of the program's implementation and activities to increase public prosperity by $38.26 \%$. Average local government capacity as measured by the efficiency ratio indicates their ability to manage their resources to produce quality service to the community is 91.21\%, thus the average local government made a saving by $8.79 \%$ of its budget. Effectiveness ratio as a proxy for the capacity of local governments to test sensitivity shows a value that indicates that they are able to manage resources effectively at 95.56\%. Meanwhile, the standard deviation indicates the volatility of the research variables.

\section{The Effect of Budget Turbulence on Budget Deviation}

Baron and Kenny (1986) state that to test for the moderating effect in the research model, the researchers shall first test the main effect. Furthermore, researchers can test the moderating effect if the main effect is significant. Table 5 presents the main effect test results, namely the effect of budget turbulence on budget deviation.

Table 5. Main Effect Test

\begin{tabular}{lccc}
\hline \multirow{2}{*}{$\begin{array}{c}\text { Independent } \\
\text { Variable }\end{array}$} & \multicolumn{3}{c}{$\begin{array}{c}\text { Least Square Method } \\
\text { Dependent Variable: }\end{array}$} \\
\cline { 2 - 4 } & Coefficient & t-statistic & Prob. \\
\hline BT & 0.0122 & 3.3893 & 0.0007 \\
\hline Constant & 0.1108 & 26.7985 & 0.0000 \\
\hline F-Statistic & 172.4296 & \\
\hline Prob (F-Statistic) & 0.0000 & \\
\hline $\mathrm{R}^{2}$ & 0.1017 & \\
\hline $\begin{array}{l}\text { Durbin-Watson Statis- } \\
\text { tic }\end{array}$ & 1.3674 & \\
\hline $\mathrm{N}$ & 1.524 & \\
\hline Note: Correction heteroscedasticity uses the Huber-White- \\
Hinkley (HC1) heteroscedasticity Consistent Standard Error \\
and Covariance
\end{tabular}


budget deviations. Thus, the purpose of this study is to examine and analyze how local governments' ability can affect relationship between budget turbulence and budget deviation.

\section{Budget Turbulence and Budget Devia- tion}

Budget turbulence is the instability of resource availability needed to compile a budget, that can threaten the effectiveness of the implementation of programs aimed to enhance people's welfare. Causes of budget turbulence are (1) developments in the micro and macro economic environment; (2) changes in government policies, such as fiscal and monetary policies; (3) income predictions not reaching the intended levels; and (4) expenditure calculations are not accurate. As a result, the planning, control, and accountability in managing the budget do not work efficiently and effectively, resulting in budget deviations.

The problem often faced by local governments in Indonesia in the budgeting process up to budget realization relates to the availability of potential resources that will be used to finance the programs. Potential resources are reflected in the regional government's projected revenue derived from local revenues, central government policies, local government policies, and micro and macro economic conditions. However, potential resources available for budgeting often fluctuate from year to year, leading to budget turbulence (Boyne \& Meier, 2009). In addition, budget turbulence occurs because the performance-based budgeting adopted by local governments closes the opportunity for incrementalism-based budgeting. Targets, spending limits, priorities, and performance levels must be set based on the performance goals of the year in question which can experience differences with the previous year. It is even possible to implement zero-based budgeting, given that needs analysis and priority activities are determined for each fiscal year (Wirasedana et al., 2018). This condition has resulted in local governments being unable to control the budget effectively and efficiently, so that it has the potential to experience budget deviations.

Budget deviation is a manifestation of information asymmetry from the aspect of agency theory. This condition occurs because the local government as an agent has more information related to budget management, such as the various changes that occur in the budget and conditions of instability of resources to develop budgets. Meanwhile, the community as principal only has information on financial reports published by the local government. The negative consequence is that those who have more information can benefit from this information asymmetry.

Findings of Wirasedana et al. (2018) show that budget turbulence has no significant effect on budget deviation. However, when budget turbulence is interacted with tight budget control it has a negative and significant influence. This effect has been demonstrated by the provincial government of Bali, where the budget turbulence that they experienced did not result in budget deviations. Level of tightness of budget control constitute the main factor in the occurrence of budget deviations. Contradicting the findings of Wirasedana et al. (2018), the finding of Johansson and Siverbo (2014) show that budget turbulence has a negative and significant effect on budget deviations and when interacted with tight budget control has a positive and significant influence on budget deviation. Based on the description, the hypothesis proposed is as follows.

H1 : Higher budget turbulence results in higher budget deviations in the district/city government. Conversely, the lower the budget turbulence, the lower the budget deviation in the district/ city government. 


\section{Budget Turbulence, Local Government Ability, and Budget Deviation}

Johansson and Siverbo (2014) explain that budgeting and budget control are central in planning, control, and accountability in public sector organizations. An important reason for budgeting in public sector organizations is that allocated resources must be used to enhance the people's prosperity. If economic resources stated in the budget are not used efficiently and effectively, it would imply that the realization of political priorities has not been carried out optimally and can reduce benefits for the welfare of society (Johansson \& Siverbo, 2014). The realization of political priorities that are not carried out optimally can be known through the existence of variance in budget calculations, surpluses or deficits. Surplus shows the inability and indiscipline of the government in compiling and realizing the budget (Johansson \& Siverbo, 2014), illegitimate because politically the allocation of resources should be used to improve people's welfare (Wirasedana et al., 2018), and can cause issues or adverse reactions such as from the media, nongovernmental organizations, and even the public, conveying the impression that the local government cannot use public funds available for the public interest (Wildavsky, 1975). Meanwhile, budget deficit indicates economic difficulties that force the local government to reduce spending and control inadequate budget.

Failure of the government to control budget that can result in surplus (under-spending) or deficits (over-spending) in the budget is referred to as budget deviation. Budget deviation reflects the inability of the local government to plan, control and account for the management of budgets, rendering its performance to become ineffective. One of the factors that contribute to budget deviation is budget turbulence. Budget turbulence shows instability in resource availability to develop budgets, potentially threatening the effectiveness of the implementation of programs and activities aimed to improve the welfare of the community.

An important factor that can reduce the influence of budget turbulence on budget deviations is the ability of the local government, namely its ability of to implement public policies through the management of its available resources to produce maximum service quality to ultimately improve the welfare of the community. Competence of the local government is an important prerequisite for government officials to carry out government activities with the aim of increasing efficiency and effectiveness in order to achieve public welfare. Capable regional governments will be able to make public policy decisions to achieve efficiency and effective management of government resources. The skills of the local government are based on experience, and their ability within the domain of public policy, strategy, and information technology. Efficiency efforts carried out by local governments represent how well they can manage resources optimally, so as to improve public services with the aim of bringing prosperity to the people. Capable regional governments are able to manage and overcome instability with the available resources, thereby minimizing the occurrence of budget deviations.

Findings of Hamid (2018) show that regional financial performance in the form of regional independence, efficiency, effectiveness, and harmony in government financial expenditure have a positive and significant effect on the level of public welfare. Furthermore, the findings of Riswan and Affandi (2014) show that regional financial performance has a positive and significant effect on capital expenditure for public services. The two findings of this study prove that local governments are able to manage their resources to improve the quality of public services, thus affecting the quality of improving people's 
The researchers tested the assumptions of heteroscedasticity and autocorrelation before testing the main effects. The results of the Durbin-Watson (DW) test show a value of 1.3674. This value is in the range of -2 to +2 , so this research model is free from autocorrelation problems. The result of the main effect test indicates that this research model fulfills the goodness-of-fit-assumption. Furthermore, the $\mathrm{R}^{2}$ value indicates that budget deviation can be explained by variations in the budget turbulence at $10.17 \%$, while the other $89.83 \%$ is due to other factors. Testing of the first hypothesis (H1) through the main effect, namely, the effect of budget turbulence on the budget deviation, shows that budget turbulence has a positive and significant effect on budget deviation. Thus, the first hypothesis (H1) is supported.

Budget turbulence is a condition of instability of resources used to compile a budget that can threaten the effectiveness of the implementation of programs and activities in order to improve public welfare. Data on the budget turbulence average shows $38.26 \%$ for local the governments during the 2015-2017 period. Such data proves that the budget turbulence is an important factor that contribute to the occurrence of budget deviation in the local government. This condition indicates that local governments tend to experience constraints in the form of resource instability in budgeting, threatening the effectiveness of program implementation aimed to improve public welfare. As a result, the budgeting process becomes less effective and accurate, causing local governments to fail to control their budget and lead to underspending or budget deficit. Occurrence of budget deviations signifies that a local government has failed to create superior public policies.

Nugroho (2017) states that the governments fail to build great and superior public policies due to two important factors, namely, (1) not understanding the meaning and substance of public policy, and (2) unavailability of public policy analysts, or, they may be available but fail to work effectively, or if they work effectively, their work may not have been able to produce great policies. As a result, the local governments fail to control budget deviations.

The findings of this study are inconsistent with the finding of Wirasedana et al. (2018) that budget turbulence has no significant effect on budget deviation. However, when budget turbulence interacts with tight budget control it has influence on budget deviations. The findings of Johansson and Siverbo (2014) also show that budget turbulence has a positive and significant effect on budget deviations when interacted with tight budget controls.

\section{The Effect of Budget Turbulence on Budget Deviation Moderated by the Skills of the Local Government}

This study examines the effect of budget turbulence on budget deviation with local government capacity measured by efficiency ratio as a moderating variable. Therefore, to test the moderating effect, the researchers first tested multicollinearity as shown in table 6 .

Table 6 shows the results of the multicollinearity test through tolerance and VIF. The TOL and VIF values of the budget deviation are $0.899>0.1$ and $1.112<10$; efficiency ratio is $0.168>0.1$ and $5.952<10$; interactions between budget turbulence and efficiency ratio are $0.909>0.1$ and $1,100<10$. Thus this study did not experience multicollinearity problems between the independent variables. The heteroscedasticity tests use White's heteroscedasticity-consistent variance and standard error, so that the test results can be directly used in the hypothesis decision making process. Furthermore, results of the Durbin-Watson (DW) test show a value of 1.9880. This value is in the range of -2 to +2 , 
and as such this research model is free from autocorrelation problems.

Table 6. Multicollinearity Test

\begin{tabular}{lccc}
\hline Variables & $\mathbf{R}^{2}$ & $\begin{array}{c}\text { TOLERENCE } \\
\left(\mathbf{1}-\mathbf{R}^{\mathbf{2}}\right)\end{array}$ & $\begin{array}{c}\text { VIF } \\
(\mathbf{1} / \mathrm{TOL})\end{array}$ \\
\hline BT & 0.101 & 0.899 & 1.112 \\
\hline ESR & 0.832 & 0.168 & 5.952 \\
\hline BT X ESR & 0.091 & 0.909 & 1.100 \\
\hline
\end{tabular}

Notes:

BT= = Budget Turbulence

ESR = Efficiency Ratio

BT XESR = Interaction between Budget Turbulence and Efficiency Ratio

Table 7 shows that the $\mathrm{F}$ statistic value and the $\mathrm{F}$ probability of statistics indicates that this research model fulfills the goodness-offit assumption. Next, the value of $\mathrm{R}^{2}$ shows

Table 7. Moderating Effect Test

\begin{tabular}{lccc}
\hline \multirow{2}{*}{$\begin{array}{c}\text { Independent } \\
\text { Variables }\end{array}$} & \multicolumn{3}{c}{$\begin{array}{c}\text { Least Square Method } \\
\text { Dependent Variable: BD }\end{array}$} \\
\cline { 2 - 4 } & Coefficient & t-statistic & Prob. \\
\hline BT & 0.0320 & 16.3853 & 0.0000 \\
\hline ESR & -0.0133 & -16.3408 & 0.0000 \\
\hline BT X ESR & -0.0005 & -12.6155 & 0.0000 \\
\hline Constant & 1.3353 & 17.6426 & 0.0000 \\
\hline F-Statistic & \multicolumn{3}{c}{3220.2350} \\
\hline
\end{tabular}

\begin{tabular}{lc} 
F-Statistic & 3220.2350 \\
\hline Prob (F-Statistic) & 0.0000 \\
\hline $\mathrm{R}^{2}$ & 0.8640 \\
\hline
\end{tabular}

$\begin{array}{ll}\text { Adjusted } \mathrm{R}^{2} & 0.8637\end{array}$

\begin{tabular}{lc}
\hline Durbin-Watson Statistic & 1.9880 \\
\hline $\mathrm{N}$ & 1524 \\
\hline $\begin{array}{l}\text { Note: Correction heteroscedasticity uses the Huber-White- } \\
\text { Hinkley (HC1) heteroscedasticity Consistent Standard Error } \\
\text { and Covariance }\end{array}$ \\
\hline
\end{tabular}

\section{Notes:}

$\mathrm{BD}=$ Budget Deviation

BT = Budget Turbulence

ESR = Efficiency Ratio

BT X ESR = Interaction between Budget Turbulence and Efficiency Ratio that budget deviation can be explained by variations in budget turbulence, efficiency ratio, and interactions between the budget turbulence and efficiency ratio of $86.40 \%$, while the other $13.06 \%$ is due to other factors. The testing of the second hypothesis (H2) through the moderating effect, namely the effect of budget turbulence on budget deviation moderated by the skills of the local government, generates a coefficient value of -0.0006, t-statistic of -12.6155, and probability value of 0 . The results of this test prove that capacity of local governments can reduce the influence of budget turbulence on the budget deviation. Thus, the second hypothesis (H2) is supported.

Capacity of local government refers to their ability to implement public policies through the management of their own resources at a minimum to produce maximum service quality in order to enhance public welfare. Competence of the local government is one of the important prerequisites for government officials to carry out government activities with the aim of increasing efficiency in order to achieve public welfare. Capable regional governments are able to make public policy decisions to achieve a high level of efficiency in managing government resources. The skills of local governments are acquired through experience including their understanding of public policies, strategies and technology. Efficiency efforts carried out by regional governments as a representation of their skills would show that local governments are able to manage resources optimally, thereby increasing public services to achieve public welfare. Capable regional governments are able to manage and overcome instability in the availability of resources, thereby minimizing the occurrence of budget deviations.

Testing of the moderation effect also proves that the budget turbulence has a positive and significant effect on budget deviation. 
The results of this test are consistent with the results of test conducted on the main effects. Furthermore, the skill of the local government exhibits a coefficient value of -0.0133, $t$ -statistic value of -16.3408 , and probability value of 0 . This finding shows that the skills of local governments have a negative and significant effect on budget deviation. The average skill score of the local governments is 91.21\% for the 2015-2017 period. This data shows that local governments are able to achieve expenditure efficiency by $8.79 \%$, thus proving that they are able to plan, manage and control the budget efficiently, thereby reducing budget deviation and ultimately improve the quality of services delivered to the community.

The findings of this study are consistent with Hamid's research findings (2018), indicating that efficiency can improve people's welfare, and the findings of Riswan and Affandi (2014), showing that efficiency can increase capital expenditure for public services. The World Economic Forum (2015) states that government efficiency is associated with a reduction in regulatory burdens, increased transparency of regulations, and reduction in wasteful costs. Lee and Whitford (2009) and Portes and Haller (2010) state that the efficiency of local government will improve performance, so that the quality of the public welfare services can be improved.

\section{Sensitivity Test on Moderating Effect with Effectiveness Ratio}

This study uses a sensitivity test through an Effectiveness ratio proxy as a proxy for local government skills. The aim is to improve the accuracy of the research results. Table 8 shows the sensitivity test for the moderating effect.

The sensitivity testing of the moderating effect as shown in table 8 indicates that the budget turbulence exhibits a coefficient value of 0.0241, t-statistic value of 15.1541, and
Table 8. Moderating Effect Test

\begin{tabular}{|c|c|c|c|c|}
\hline \multirow{2}{*}{\multicolumn{2}{|c|}{$\begin{array}{c}\text { Independent } \\
\text { Variables }\end{array}$}} & \multicolumn{3}{|c|}{$\begin{array}{l}\text { Least Square Method } \\
\text { Dependent Variable: BD }\end{array}$} \\
\hline & & Coefficient & t-statistic & Prob. \\
\hline \multicolumn{2}{|l|}{ BT } & 0.0241 & 15.1541 & 0.0000 \\
\hline \multicolumn{2}{|l|}{ EFR } & -0.0107 & -19.4102 & 0.0000 \\
\hline \multicolumn{2}{|l|}{ BT X EFR } & -0.0003 & -7.5242 & 0.0000 \\
\hline \multicolumn{2}{|l|}{ Constant } & 1.1370 & 21.2082 & 0.0000 \\
\hline \multicolumn{2}{|l|}{ F-Statistic } & \multicolumn{3}{|c|}{572.2599} \\
\hline \multicolumn{2}{|c|}{ Prob (F-Statistic) } & \multicolumn{3}{|c|}{0.0000} \\
\hline \multicolumn{2}{|l|}{$R^{2}$} & \multicolumn{3}{|c|}{0.5303} \\
\hline \multicolumn{2}{|c|}{ Adjusted $\mathrm{R}^{2}$} & \multicolumn{3}{|c|}{0.5294} \\
\hline \multicolumn{2}{|c|}{ Durbin-Watson } & \multicolumn{3}{|c|}{1.8833} \\
\hline \multicolumn{2}{|l|}{$\mathrm{N}$} & \multicolumn{3}{|c|}{1524} \\
\hline \multicolumn{5}{|c|}{$\begin{array}{l}\text { Note: Correction heteroscedasticity uses the Huber-White- } \\
\text { Hinkley (HC1) heteroscedasticity Consistent Standard Error } \\
\text { and Covariance }\end{array}$} \\
\hline \multicolumn{5}{|l|}{ Notes: } \\
\hline $\mathrm{BD}$ & \multicolumn{4}{|c|}{ = Budget Deviation } \\
\hline EFR & \multicolumn{4}{|c|}{ = Effectiveness Ratio } \\
\hline BT & \multicolumn{4}{|c|}{$=$ Budget Turbulence } \\
\hline BT X EFR & \multicolumn{4}{|c|}{$\begin{array}{l}=\text { Interaction between Budget Turbulence } \\
\text { and Effectiveness Ratio }\end{array}$} \\
\hline
\end{tabular}

probability value of 0 . This finding proves that budget turbulence has a positive and significant effect on budget deviation. The results of this test are consistent with the results of testing conducted on the main effects. The skills of the local government exhibits a coefficient value of -0.0107 , tstatistic value of -19.4102 , and probability value of $o$. This finding shows that the skills of local governments have a negative and significant effect on budget deviation. The average skill score of local government is 95.56\% for the 2015-2017 period. This data shows that the local governments are effective in managing resources, resulting in high budget realization. Capable regional governments would be able to plan, manage and control the budget effectively, thereby reducing budget deviation. Finally, local governments can improve the quality of services 
delivered to the public. This finding is consistent with previous tests.

The effect of budget turbulence on budget deviation moderated by the skills of the local government exhibits a coefficient value of -0.0003, t-statistic value of -7.5242, and probability value of 0 . The results of this test prove that capacity of local governments can reduce the influence of budget turbulence on budget deviation. This finding shows that the skills of local governments that are implemented through effective public policies can reduce the influence of budget turbulence on budget deviations.

Public policies that are effectively implemented show that local governments can use their managerial skills to manage government resources. The aim is to improve the quality of services in order to achieve the welfare of a just and prosperous society. Hamid (2018) states that effectiveness is related to the degree of success of an operation in public sector organizations, so that an activity is said to be effective if the activity has a major influence on the ability to provide community services which are predetermined targets. Effectiveness focuses on outcome or outcomes and is interpreted as the relationship between the output of the accountability center and its objectives or targets (Yaqin et al., 2018). The findings of this study are consistent with $\mathrm{Ha}$ mid's research findings (2018) showing that effectiveness can improve people's welfare, and the findings of Riswan and Affandi (2014), showing that effectiveness can increase capital expenditure for public services.

\section{Sensitivity Test Categorized by Main Geographical Regions}

This study uses descriptive statistics to briefly explain the research variables in the sensitivity test categorized by the primary geographical regions in Indonesia, namely, (1) western Indonesia, (2) central Indonesia, and (3) eastern Indonesia. Table 9 presents the results of the descriptive statistical test.

The mean value of budget deviation among western, central and eastern parts of Indonesia as shown in Table 9 indicates that the average failure of the local governments in controlling the budget which can cause surpluses or deficits is $10.99 \%$ in the local governments in western Indonesia, 12.67\% among those in central Indonesia and $11.42 \%$ among local governments in eastern Indonesia. Furthermore, the mean value of budget turbulence indicates that the local governments are experiencing conditions of resource instability in developing their respective budgets, threatening the effectiveness of program implementation and activities to improve community welfare amounting by $15.78 \%, 86.88$, and $27.79 \%$. The average efficiency ratio in the western region of Indonesia, central Indonesia and eastern Indonesia

Table 9. Descriptive Statistics

\begin{tabular}{|c|c|c|c|c|c|c|c|c|c|}
\hline \multirow[b]{2}{*}{ Variables } & \multicolumn{3}{|c|}{ Western Region } & \multicolumn{3}{|c|}{ Central Region } & \multicolumn{3}{|c|}{ Eastern Region } \\
\hline & $\mathbf{N}$ & Mean & Std. Dev & $\mathbf{N}$ & Mean & Std. Dev & $\mathbf{N}$ & Mean & Std. Dev \\
\hline BD & 885 & 0.1099 & 0.1691 & 450 & 0.1269 & 0.1810 & 189 & 0.1142 & 0.1423 \\
\hline BT & 885 & 0.1578 & 0.2260 & 450 & 0.8688 & 8.1316 & 189 & 0.2779 & 0.5458 \\
\hline ESR & 885 & 91.5695 & 10.8887 & 450 & 90.5383 & 11.9158 & 189 & 91.1867 & 11.9357 \\
\hline EFR & 885 & 96.5139 & 10.3379 & 450 & 94.4499 & 11.0658 & 189 & 93.7962 & 9.4843 \\
\hline \multicolumn{10}{|l|}{ Notes: } \\
\hline $\mathrm{BD}$ & \multicolumn{9}{|c|}{ = Budget Deviation } \\
\hline BT & \multicolumn{9}{|c|}{$=$ Budget Turbulence } \\
\hline ESR & \multicolumn{9}{|c|}{ = Efficiency Ratio } \\
\hline
\end{tabular}

Volume 5, Number 1, 2019: 1-20 
is $91.56 \%$, $90.53 \%$, and $91.18 \%$, respectively, indicating that the ability of local governments to manage their resources to produce a quality service to the community is $8.44 \%$, $9.47 \%$ and $8.82 \%$, respectively. Finally, the average effectiveness ratios in western Indonesia, central Indonesia, and eastern Indonesia of $96.51 \%, 94.44 \%$, and $93.79 \%$, respectively, indicates that the ability of local governments to manage their resources effectively to produce quality services to the community is sufficiently high. Meanwhile, standard budget deviation for the three geographical categories given an indication of the volatility of the research variable.

\section{Main Effect Sensitivity Test}

The results of the main effect sensitivity test on the effect of budget turbulence on the budget deviation for the western, central, and eastern parts of Indonesia are shown in table 10.
The sensitivity testing of the moderating effect as presented in table 10 shows the test results for western, central and eastern Indonesia having a statistical $\mathrm{F}$ and statistical $\mathrm{F}$ probability value that indicates this research model fulfills the goodness-of-fit assumption. The value of $\mathrm{R}^{2}$ shows that budget deviation can be explained by variations in the budget turbulence at $16.89 \%$, with the other 83.11\% due to other factors for local governments in the western part of Indonesia, $26.43 \%$ with the other $73.57 \%$ due to other factors for local governments in central Indonesia, and $33 \%$ with the other $67 \%$ due to other factors for local governments in eastern Indonesia. Testing of the first hypothesis (H1) through the main effect, namely, the effect of budget turbulence on the budget deviation, shows that, for western Indonesia, the coefficient value is 0.3076 , t-statistic is 4.3327 , and probability is $\mathrm{o}$, proving that budget turbulence has a positive and significant effect on budget deviation for that re-

Table 10. Main Effect Test

\begin{tabular}{|c|c|c|c|c|c|c|c|c|c|}
\hline \multirow{3}{*}{$\begin{array}{c}\text { Indepen- } \\
\text { dent } \\
\text { Variable }\end{array}$} & \multicolumn{9}{|c|}{$\begin{array}{l}\text { Least Square Method } \\
\text { Dependent Variable: BD }\end{array}$} \\
\hline & \multicolumn{3}{|c|}{ Western Region } & \multicolumn{3}{|c|}{ Central Region } & \multicolumn{3}{|c|}{ Eastern Region } \\
\hline & Coefficient & t-statistic & Prob. & Coefficient & t-statistic & Prob. & Coefficient & t-statistic & Prob. \\
\hline BT & 0.3076 & 4.3327 & 0.0000 & 0.0114 & 3.3216 & 0.0010 & 0.1498 & 4.3961 & 0.0000 \\
\hline Constant & 0.0613 & 5.8708 & 0.0000 & 0.1170 & 16.5316 & 0.0000 & 0.0726 & 6.9956 & 0.0000 \\
\hline F-Statistic & \multicolumn{3}{|c|}{179.5433} & \multicolumn{3}{|c|}{161.0147} & \multicolumn{3}{|c|}{92.1098} \\
\hline $\begin{array}{l}\text { Prob. (F- } \\
\text { Statistic) }\end{array}$ & \multicolumn{3}{|c|}{0.0000} & \multicolumn{3}{|c|}{0.0000} & \multicolumn{3}{|c|}{0.0000} \\
\hline$R^{2}$ & \multicolumn{3}{|c|}{0.1689} & \multicolumn{3}{|c|}{0.2644} & \multicolumn{3}{|c|}{0.3300} \\
\hline $\begin{array}{l}\text { Durbin- } \\
\text { Watson } \\
\text { Statistic }\end{array}$ & \multicolumn{3}{|c|}{1.7701} & \multicolumn{3}{|c|}{1.0804} & \multicolumn{3}{|c|}{1.3240} \\
\hline $\mathrm{N}$ & \multicolumn{3}{|c|}{885} & \multicolumn{3}{|c|}{450} & \multicolumn{3}{|c|}{189} \\
\hline
\end{tabular}

Note: Correction heteroscedasticity uses the Huber-White-Hinkley (HC1) heteroscedasticity Consistent Standard Error and Covariance

Notes:

BD $\quad$ Budget Deviation

BT = Budget Turbulence 
gion. For central Indonesia, the effect of budget turbulence on budget deviation generates a coefficient value of 0.0114 , $t-$ statistic value of 3.3216 , and probability value of 0.0010 , proving that budget turbulence has a positive and significant effect on the budget deviation for the central Indonesian category. For western Indonesia, the effect of budget turbulence on budget deviation generates a coefficient value of $0.1498, \mathrm{t}$ -statistic value of 4.3961, and probability value of o, proving that budget turbulence has a positive and significant effect on the budget deviation for the eastern Indonesia category. Thus, the results of this sensitivity test are consistent with the results of previous tests. The results of the sensitivity test of the effect of moderating the effect of budget turbulence on the budget deviation through the skills of local governments for western, central, and eastern Indonesia is shown in table 11.

Sensitivity testing of the moderating effect in table 12 shows the test results for the western, central and eastern parts of Indonesia, with a statistical $\mathrm{F}$ and statistical $\mathrm{F}$ probability value, indicating that this research model fulfills the goodness-of-fit assumption. Furthermore, the value of $\mathrm{R}^{2}$ shows that, for western Indonesia, budget deviation can be explained by variations in budget turbulence, local government skills, and interactions between such skills $84.42 \%$, while the other $15.58 \%$ is due to other factors. For central Indonesia, budget deviation can be explained by variations in budget turbulence, local government skills, and interactions between such skills at $97.67 \%$, while the other $2.33 \%$

Table 11. Moderating Effect Test

\begin{tabular}{|c|c|c|c|c|c|c|c|c|c|}
\hline \multirow{3}{*}{$\begin{array}{l}\text { Independent } \\
\text { Variable }\end{array}$} & \multicolumn{9}{|c|}{$\begin{array}{l}\text { Least Square Method } \\
\text { Dependent Variable: BD }\end{array}$} \\
\hline & \multicolumn{3}{|c|}{ Western Region } & \multicolumn{3}{|c|}{ Central Region } & \multicolumn{3}{|c|}{ Eastern Region } \\
\hline & Coefficient & t-statistic & Prob. & Coefficient & t-statistic & Prob. & Coefficient & t-statistic & Prob. \\
\hline BT & 1.1687 & 3.5256 & 0.0004 & 0.02995 & 47.5285 & 0.0000 & 0.3557 & 2.8761 & 0.0045 \\
\hline ESR & -0.0124 & -9.6008 & 0.0000 & -0.0131 & -45.5369 & 0.0000 & -0.0109 & -9.5751 & 0.0000 \\
\hline BT X ESR & -0.0136 & -3.4831 & 0.0005 & -0.0005 & -40.4129 & 0.0000 & -0.0045 & -2.9041 & 0.0000 \\
\hline Constant & 1.2395 & 9.9757 & 0.0000 & 1.3147 & 49.6477 & 0.0000 & 1.1186 & 10.7079 & 0.0000 \\
\hline F-Statistic & \multicolumn{3}{|c|}{1592.351} & \multicolumn{3}{|c|}{6236.466} & \multicolumn{3}{|c|}{1054.129} \\
\hline $\begin{array}{l}\text { Prob. (F- } \\
\text { Statistic) }\end{array}$ & \multicolumn{3}{|c|}{0.0000} & \multicolumn{3}{|c|}{0.0000} & \multicolumn{3}{|c|}{0.0000} \\
\hline $\mathrm{R}^{2}$ & \multicolumn{3}{|c|}{0.8443} & \multicolumn{3}{|c|}{0.9767} & \multicolumn{3}{|c|}{0.9447} \\
\hline Adjusted $\mathrm{R}^{2}$ & \multicolumn{3}{|c|}{0.8437} & \multicolumn{3}{|c|}{0.9765} & \multicolumn{3}{|c|}{0.9438} \\
\hline $\begin{array}{l}\text { Durbin- } \\
\text { Watson Statis- } \\
\text { tic }\end{array}$ & \multicolumn{3}{|c|}{1.9099} & \multicolumn{3}{|c|}{1.9244} & \multicolumn{3}{|c|}{1.7168} \\
\hline $\mathrm{N}$ & \multicolumn{3}{|c|}{885} & \multicolumn{3}{|c|}{450} & \multicolumn{3}{|c|}{189} \\
\hline
\end{tabular}

Note: Correction heteroscedasticity uses the Huber-White-Hinkley (HC1) heteroscedasticity Consistent Standard Error and Covariance

Notes:

$\mathrm{BD}=$ Budget Deviation

BT= Budget Turbulence

ESR = Efficiency Ratio

BT X ESR = Interaction between Budget Turbulence and Efficiency Ratio 
is due to other factors. For eastern Indonesia, budget deviation can be explained by variations in budget turbulence, local government skills, and interactions such skills at $94.47 \%$, while the other $5.53 \%$ is due to other factors.

Testing of the moderation effect as presented in table 11 shows that the effect of budget turbulence on budget deviation, for western Indonesia, generates a coefficient value of 1.1687 , t-statistic value of 3.5256 , and probability value of 0.0004 , thus proving that budget turbulence has a positive and significant effect on budget deviation that region. For central Indonesia, the effect of budget turbulence on budget deviation generates a coefficient value of 0.0299 , $t$-statistic value of 47.5285 , and probability value of $o$, thus proving that budget turbulence has a positive and significant effect on budget deviation for that region. For eastern Indonesia, the effect of budget turbulence on budget deviation generates a coefficient value of 0.3557 , t-statistic value of 2.8761 , and probability value of 0 , thus proving that budget turbulence has a positive and significant effect on budget deviation for that region. As such, the results of this sensitivity test are consistent with the results of previous tests.

Testing of the moderation effect as presented in Table 11 shows that, for western Indonesia, the effect of local government skills on budget deviation generates a coefficient value of -0.0124, t-statistic of -9.6008, and probability value of $o$, proving that the skills of the local governments in that region have a negative and significant effect on budget deviation. For central Indonesia, the effect of local government skills on budget deviation generates a coefficient value of -0.0131, tstatistic value of -45.5369 , and probability value of $o$, thus proving that the skills of the regional government in that region have a negative and significant effect on budget deviation. For eastern Indonesia, the effect of local government skills on budget deviation generates a coefficient value of -0.0109, tstatistic value of -9.5751 , and probability value of $o$, proving that the skills of the local governments in that region have a negative and significant effect on budget deviation. Therefore, the results of this sensitivity test are consistent with the results of previous tests.

The second hypothesis testing (H2) on moderation effect shows that, for western Indonesia, coefficient value is at -0.0136, tstatistic is at -3.4831 , and probability value is at 0.0005 , proving that the skills of the local governments in that region have a negative and significant effect on the relationship between budget turbulence and budget deviation. For central Indonesia, the coefficient value is at -0.0005, t-statistic value is at 40.4128, and probability value is at 0.0000 , proving that the skills of the local government have a negative and significant effect on the relationship between budget turbulence and budget deviation for the region. For eastern Indonesia, coefficient value is at -0.0046, t-statistic value is at -2.9041 , and probability value is at 0.0000 , proving that the skills of the local government have a negative and significant effect on the relationship between budget turbulence and budget deviation for the region. Therefore, the results of this sensitivity test are consistent with the results of previous tests.

\section{Sensitivity Test of Moderating Effect through Effectiveness Ratio Categorized by Region}

Result of sensitivity test of moderating effect through effectiveness ratio as a proxy for the skills of local governments categorized by main geographical regions of western, central, and eastern Indonesia can be found in table 12.

The statistical $\mathrm{F}$ value and the statistical $\mathrm{F}$ probability for the western, central and east- 
ern Indonesian region category shown in table 12 indicates that this research model fulfills the goodness of fit assumption. Furthermore, the value of $\mathrm{R}^{2}$ shows that the budget deviation can be explained by variations in budget turbulence, local government skills, and interactions between local government skills of $44.23 \%$ and the remaining $55.77 \%$ by other factors, especially for local governments in the western Indonesia region. The deviation budget can be explained by variations in budget turbulence, local government skills, and interactions between local government skills of $73.40 \%$ and the remaining 26.6\% by other factors especially for central Indonesian region category. As for eastern Indonesia region category, the deviation budget can be explained by variations in budget turbulence, local government skills, and interactions between local government skills of $59.68 \%$ and the remaining $40.32 \%$ by other factors.

Testing of the moderation effect as presented in table 12 shows that the effect of budget turbulence on budget deviation, for eastern Indonesia, generates a coefficient value of 0.9480 , t-statistic value of 1.8644 , and probability value of 0.0626 , thus proving that budget turbulence does not have a significant effect on budget deviation for that region. For central Indonesia, the effect of budget turbulence on budget deviation generates a coefficient value of 0.0246 , t-statistic value of 18.3627 , and probability value of $o$, thus proving that budget turbulence has a positive and significant effect on budget deviation for that region. For eastern Indonesia, the effect of budget turbulence on budget deviation generates a coefficient value of 0.0234 , $t$ statistic value of 0.1459 , and probability value of 0.8841 . The results of this test prove that budget turbulence does not have a significant effect on the budget deviation for the eastern Indonesia category. Thus, the results of this sensitivity test are consistent only for local governments in central Indonesia.

Table 12. Moderating Effect Test

\begin{tabular}{|c|c|c|c|c|c|c|c|c|c|}
\hline \multirow{3}{*}{$\begin{array}{l}\text { Independent } \\
\text { Variable }\end{array}$} & \multicolumn{9}{|c|}{$\begin{array}{l}\text { Least Square Method } \\
\text { Dependent Variable: BD }\end{array}$} \\
\hline & \multicolumn{3}{|c|}{ Western Region } & \multicolumn{3}{|c|}{ Central Region } & \multicolumn{3}{|c|}{ Eastern Region } \\
\hline & Coefficient & t-statistic & Prob. & Coefficient & t-statistic & Prob. & Coefficient & t-statistic & Prob. \\
\hline BT & 0.9480 & 1.8644 & 0.0626 & 0.0246 & 18.3627 & 0.0000 & 0.0234 & 0.1459 & 0.8841 \\
\hline EFR & -0.0086 & -13.9143 & 0.0000 & -0.0112 & -18.7760 & 0.0000 & -0.0091 & -9.4375 & 0.0000 \\
\hline BT X EFR & -0.0096 & -1.7508 & 0.0803 & -0.0003 & -9.6906 & 0.0000 & 0.0005 & 0.2500 & 0.8028 \\
\hline Constant & 0.9295 & 14.5840 & 0.0000 & 1.1812 & 20.5243 & 0.0000 & 0.9485 & 9.9316 & 0.0000 \\
\hline F-Statistic & \multicolumn{3}{|c|}{232.9503} & \multicolumn{3}{|c|}{410.3773} & \multicolumn{3}{|c|}{91.3106} \\
\hline Prob. (F-Statistic) & \multicolumn{3}{|c|}{0.0000} & \multicolumn{3}{|c|}{0.0000} & \multicolumn{3}{|c|}{0.0000} \\
\hline $\mathrm{R}^{2}$ & \multicolumn{3}{|c|}{0.4423} & \multicolumn{3}{|c|}{0.7340} & \multicolumn{3}{|c|}{0.5968} \\
\hline Adjusted $\mathrm{R}^{2}$ & \multicolumn{3}{|c|}{0.4404} & \multicolumn{3}{|c|}{0.7322} & \multicolumn{3}{|c|}{0.5903} \\
\hline $\begin{array}{l}\text { Durbin-Watson } \\
\text { Statistic }\end{array}$ & \multicolumn{3}{|c|}{1.9523} & \multicolumn{3}{|c|}{1.7053} & \multicolumn{3}{|c|}{1.7327} \\
\hline $\mathrm{N}$ & \multicolumn{3}{|c|}{885} & \multicolumn{3}{|c|}{450} & \multicolumn{3}{|c|}{189} \\
\hline
\end{tabular}

Note: Correction heteroskedasticity use Huber-White-Hinkley (HC1) heteroskedasticity Consistent Standard Error and Covariance 
Testing of the moderating effect in Table 12 shows that, for western Indonesia, the influence of skills of the local governments on budget deviation shows a coefficient value of -0.0086, t-statistic of -13.9143 , and probability value of 0 , proving that the skills of local governments have a negative and significant effect on budget deviation. For central Indonesia, the effect of local government skills on budget deviation shows a coefficient value of -0.0112, t-statistic value of -18.7760 , and probability value of $\mathrm{o}$, proving that the skills of local governments have a negative and significant effect on budget deviation in that region. For eastern Indonesia, the effect of local government skills on budget deviation shows a coefficient value of -0.0091, t-statistic value of -9.4375 , and probability value of $o$, thus proving that the skills of local governments have a negative and significant effect on budget deviation in that region. Thus, the results of this sensitivity test are consistent with the results of previous tests.

The testing of the second hypothesis (H2) through the moderating effect, namely, the effect of budget turbulence on budget deviation with the skill of the local government as moderator, shows, for western Indonesia, a coefficient value of -0.0136, t-statistic value of -3.4831 , and probability value of 0.0005 , thus proving that the skills of local governments have a negative and significant effect on the relationship between budget turbulence and budget deviation in that region. For central Indonesia, the effect of budget turbulence on budget deviation with the skills of the local government as moderator shows a coefficient value of -0.0005 , $t-$ statistic value of -40.4129 , and probability value of 0 , proving that the skills of local governments have a negative and significant effect on the relationship between budget turbulence and budget deviation in that region. For eastern Indonesia, the effect of budget turbulence on budget deviation with the skills of the local government as modera- tor shows a coefficient value of -0.0045, $\mathrm{t}$ statistic value of -2.9041 , and probability value of o, proving that the skills of local governments have a negative and significant effect on the relationship between budget turbulence and budget deviation in that region. Therefore, the results of this sensitivity test are consistent with the results of previous tests.

\section{CONCLUSION}

This study is a modification of the development of previous research models. The main issue of this study are the processes relating to planning, control, and accountability in the management of local government budgets in Indonesia for the 2015-2017 period, which were not carried out efficiently and effectively and thus causing budget deviations. Budget deviations can be recognized through the existence of variance between budget and realization, in the form of surpluses or deficits. Budget variance signifies that a local government has failed to build superior public policies. A surplus proves that a local government suffers a lack of competence and discipline in compiling and realizing its budget. Meanwhile, a deficit proves that the local government in question experiences economic difficulties and inadequate budget control.

The findings of this study prove that budget turbulence has a positive and significant effect on budget deviation, and adequate capacity of the local government can reduce the effect of budget turbulence on budget deviation, both using efficiency and effectiveness ratios in measuring such government capacity. The findings of the sensitivity test using (1) the effectiveness ratio as a proxy for local government skills, and (2) testing by the main regions in Indonesia, namely western, central and eastern Indonesia, proves that the results are consistent with the main find- 
ings. Based on its findings, this study contributes theories, methodologies and policies.

The theory being contributed based on the findings of this study stipulates that the factors causing budget turbulence are (1) expenditure efficiency and increase in productive spending to support government program priorities and encourage efficient, innovative and sustainable financing while maintaining an investment climate. Through several of these alternatives, the local government can overcome resource instability that can threaten the effectiveness of the implementation of various programs, (2) the development of the micro and macro economic environment, (3) changes in government policies, such as fiscal and monetary policies, (4) income predictions not reaching targets, and (5) shopping calculations being less accurate. Factors (1) and (2) are inherent factors that are difficult to control by local governments due to economic turmoil. Meanwhile, factors (3) and (4) are internal factors related to the character of the local regional government that can be controlled in accordance with their understanding, ability, and quality in managing public policy.

This study can provide added value for the development of science, especially public sector accounting research using secondary data. The contribution of this study is through the main test analysis and sensitivity test using proxies and other regional categories to prove the consistency of the findings, and the use of limited e-views analysis tools.

Meanwhile, the contribution of this study's findings to government policy in Indonesia is the recommendation that the government should evaluate its strengths, weaknesses, opportunities, and threats through SWOT analysis to avoid or control the effects of budgetary turbulence on budget irregularities. The government should also evaluate variance between budget and realization, or if possible maintain a "balance scorecard", so that performance of local governments in Indonesia are not only be measured financially but also in non-financial terms and also provide rewards and punishment to local governments to encourage improvements in performance.

Finally, this study has several limitations, namely that the measurement of budget turbulence variables and budget deviation is still limited to public sector accounting research, particularly those relating to measurements using secondary data, and the results of this study can only be generalized to district governments/cities in Indonesia within the period of 2015-2017. Therefore, further research should be able to develop a proxy for measuring budget turbulence and budget deviation to improve public sector accounting research literature, especially when using secondary data. Researchers can use samples obtained from ministries and institutions for further research using variables in this study or modify the research model used herein in accordance with the context of the research phenomenon or issue.

\section{REFERENCES}

Al-Fajri, F. (2018, September 3). Defisit anggaran APBD Rp. 900 miliar, Pemkot Bekasi gandeng KPK. Wartakota Live.com. Retrieved from http:// wartakota.tribunnews.com/ 2018/o9/o3/defisit-anggaran-apbd-rp -900-miliar-pemkot-bekasi-gandengkpk.

Anessi-Pessina, E., Barbera, C., Rota, S., Sicilia, M., \& Steccolini, I. (2012). Public: A review. In: Presented at $7^{\text {th }}$ International Conferences on Accounting, Auditing \& Management in Public Sector Reforms, Rome, Italy.

Baron, R. M., \& Kenny, D. (1986). The mod- 
erator-mediator variable distinction in social psychological research: conceptual, strategic, and statistical considerations. Journal of Personality and Social Psychology, 51(6), 1173-1182.

Boland, R. J., \& Pondy, L. R. (1986). The micro dynamics of a budget-cutting process: Modes, models and structure. Accounting, Organizations and Society, 11(4-5), 403-422.

Boyne, G. A., \& Meier, K. J. (2009). Environmental turbulence, organizational stability, and public service performance. Administration \& Society, 40(8), 799824. doi: 10.1177/0095399708326333.

Covaleski, M. A., \& Dirshmit, M. W. (1988). The use of budget symbols in the budget arena: An historical informed field study. Accounting, Organizations and Society, 13(1), 1-24.

Directorate General of Fiscal Balance. (n.d.). Data realisasi APBD. Retrieved from http://www.djpk.kemenkeu.go.id./? page_id $=316$.

Ghozali, I., \& Ratmono, D. (2017). Analisis multivariat dan ekonometrika: Teori, konsep, dan aplikasi dengan eviews 10. Semarang: Badan Penerbit Universitas Diponegoro.

Gujarati, D., \& Porter, D. C. (2009). Basic econometrics $5^{\text {th }}$ edition. New York: McGraw-Hill.

Hamid, A. A. (2018). Analisis pengaruh kinerja keuangan daerah terhadap tingkat kesejahteraan masyarakat Kabupaten Majalengka-Jawa Barat. Jurnal Sekuritas, 1(4), 38-51.

Halim, A., \& Kusufi, M. S. (2014). Akuntansi sektor publik: Akuntansi keuangan daerah. Jakarta: Penerbit Salemba Empat.

Johansson, T., \& Siverbo, S. (2014). The appropriateness of tight budget control in public sector organizations facing budget turbulence. Management Accounting Research, 26, 271-283.

Jonsson, S. (1982). Budget behavior in local government-a case study over 3 years. Accounting, Organizations and Society, $7(3), 287-304$.

Lee, S. Y., \& Whitford, A. B. (2009). Government effectiveness in comparative perspective. Journal of Comparative Policy Analysis, 11(2), 249-281.

Nugroho, R. (2017). Public policy: dinamika kebijakan publik, analisis kebijakan publik, manajemen politik kebijakan publik, etika kebijakan publik, kimia kebijakan publik. Jakarta: PT. Gramedia.

Portes, A., \& Haller, W. (2010). The Informal Economy. Retrieved from https:// www.academia.edu/29781396/ The_Informal_Economy.

Riswan, R., \& Affandi, A. (2014). Pengaruh kinerja keuangan daerah terhadap belanja modal untuk pelayanan publik dalam perspektif teori keagenan. Jurnal Akuntansi dan keuangan, 5, 71 -90 .

Santoso, S. (2010). Statistik parametrik, konsep dan aplikasi dengan SPSS. Jakarta: PT. Gramedia.

Wirasedana, I. W. P., Sisdyani, E. A., \& Setiawan, I. P. E. (2018). Kendali budget ketat pada pemda di Provinsi Bali dalam menghadapi turbulensi budget. $E$ Jurnal Akuntansi, 25(1), 300-327. doi: 10.24843/EJA.2018.v25.io1.p12.

Wildavsky, A. (1975). Budgeting: A comparative theory of budget processes. Boston: Little. Brown \& Co.

World Economic Forum. (2015). The global competitiveness report 2015-2016. Genewa: World Economic Forum.

Yaqin, U. A., Herwanti, T., \& Akram. (2018). Komitmen pemerintah daerah dalam pengelolaan anggaran pendapatan dan belanja daerah: Studi pada Pemerintah Kota Bima. E-Jurnal Akuntansi, 25(3), 2321-2351. 


\section{APPENDIX \\ Research Sample}

BUDGET TURBULENCE AND BUDGET DEVIATION : DO LOCAL GOVERNMENT ... Eva Herianti

\begin{tabular}{|c|c|c|c|}
\hline \multicolumn{2}{|c|}{ Categorization by Geographical Region } & \multicolumn{2}{|c|}{ Number Local Government } \\
\hline Regions & Province & Districts & Cities \\
\hline & 1. Aceh & 18 & 5 \\
\hline & 2. North Sumatera & 25 & 8 \\
\hline & 3. West Sumatera & 12 & 7 \\
\hline & 4. Riau & 10 & 2 \\
\hline & 5. Riau Islands & 5 & 2 \\
\hline & 6. Jambi & 9 & 2 \\
\hline & 7. Bangka Belitung Islands & 6 & 1 \\
\hline & 8. Bengkulu & 9 & 1 \\
\hline \multirow[t]{9}{*}{ Western Region } & 9. South Sumatera & 13 & 4 \\
\hline & 10. Lampung & 13 & 2 \\
\hline & 11. Banten & 4 & 4 \\
\hline & 12. West Java & 18 & 9 \\
\hline & 13. Central Java & 29 & 6 \\
\hline & 14. Yogyakarta & 4 & 1 \\
\hline & 15. East Java & 29 & 9 \\
\hline & 16. West Kalimantan & 12 & 2 \\
\hline & 17. Central Kalimantan & 13 & 1 \\
\hline
\end{tabular}




\section{Categorization by Geographical Region}

\begin{tabular}{|c|c|c|c|c|}
\hline Regions & No. & Province & Districts & Cities \\
\hline & 1. & North Kalimantan & 4 & 1 \\
\hline & 2. & South Kalimantan & 11 & 2 \\
\hline & 3. & East Kalimantan & 7 & 3 \\
\hline & 4. & Bali & 8 & 1 \\
\hline & 5. & East Nusa Tenggara & 21 & 1 \\
\hline
\end{tabular}

Central Region

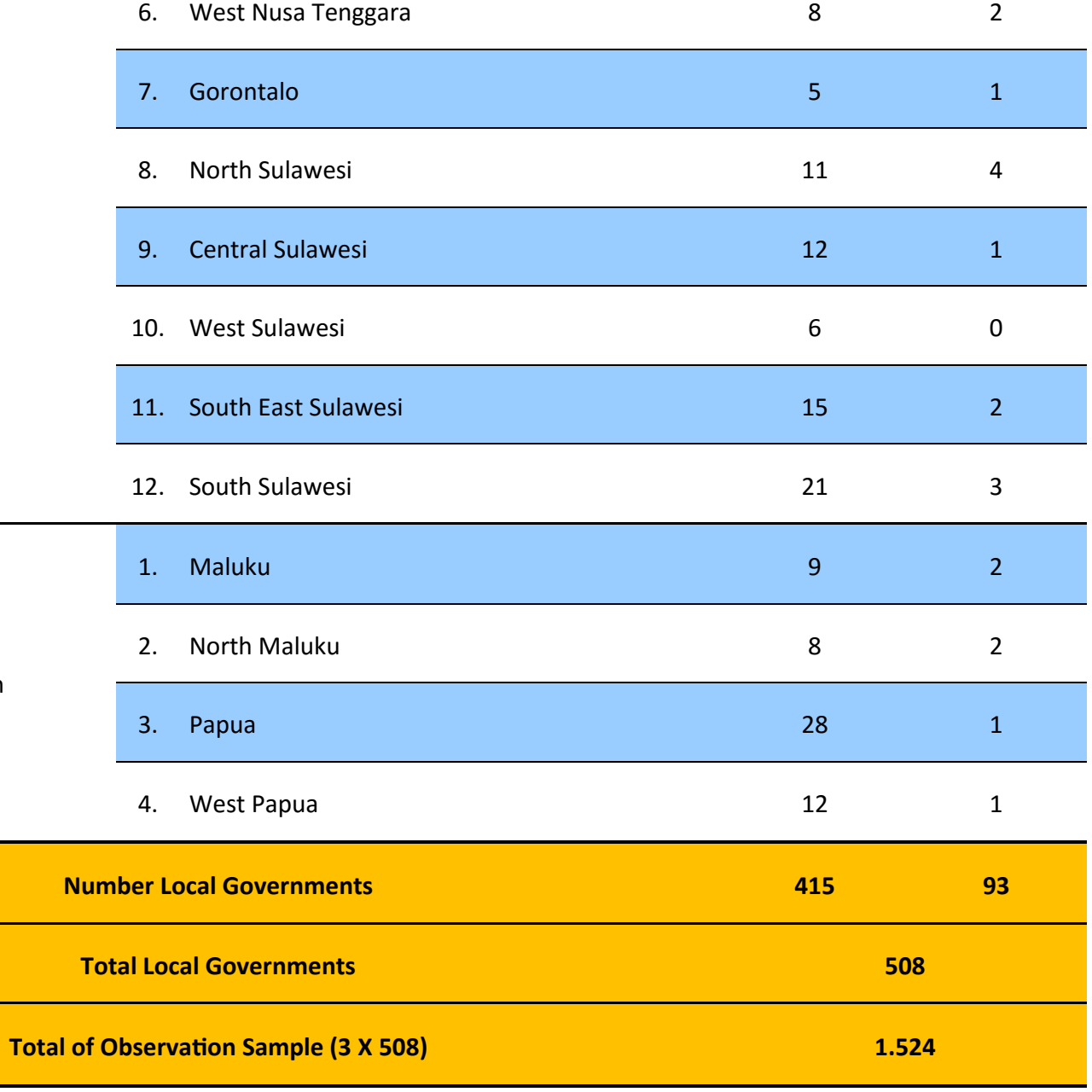

Northern Region 